\title{
COVID-19 as Natural Intervention: Guilt and Perceived Historical Privilege Contributes to Structural Reform Under Conditions of Crisis
}

\author{
Melike M. Fourie ${ }^{1} \cdot$ Wilhelm J. Verwoerd $^{1}$
}

Received: 1 December 2020 / Accepted: 12 August 2021/Published online: 30 September 2021

(c) The Society for Affective Science 2021

\begin{abstract}
The COVID-19 pandemic has been described as an unmasking of persistent racialized inequalities linked to South Africa's oppressive past. However, such observations lack empirical support. Here we examined whether COVID-19 lockdown conditions encouraged greater perceptions of continuing structural racism together with motivational and behavioral support for social justice, and whether guilt or empathic concern undergirded such responses. A national sample of White South Africans' data suggests that the pandemic served as a natural intervention, fostering greater acknowledgement of structural racism and support for redress through increased awareness of historical privilege and guilt in response to Black hardship. Guilt furthermore predicted a social justice motivation in relief efforts, whereas empathic concern predicted only charity motivation. These results suggest that "White guilt" is more consequential than empathic concern in contributing to structural reform but would require longer-term processes to support the translation of its motivational push into sustainable contributions to social justice.
\end{abstract}

Keywords Guilt $\cdot$ Empathic concern $\cdot$ Structural racism $\cdot$ Inequality $\cdot$ Social justice $\cdot$ Charity

Over the past 25 years, South Africa has increasingly featured White denial of the roots of present-day racialized inequalities (Lefko-Everett et al., 2017). Although Whiteness continues to yield significant (economic) power and privilege (Chatterjee, 2019; Ratele \& Laubscher, 2010), right-wing politics enforce the notion that the White minority is systematically oppressed and marginalized by the post-apartheid government (Van Zyl-Hermann, 2018). Such perceptions of victimhood often manifest in reduced acknowledgement and dampened empathic concern for continuing structural racism (Fourie \& Moore-Berg, 2021), which serves the added benefit of maintaining the status quo and access to tangible material advantages (Milazzo, 2016; Unzueta \& Lowery, 2008).

The unequal health and economic impact of the COVID19 pandemic has highlighted the racialized nature of divisions between rich and poor worldwide (Bottan et al.,

Handling Editor: Lasana Harris

Melike M. Fourie

marethem@gmail.com; melikef@sun.ac.za

1 Studies in Historical Trauma and Transformation, Stellenbosch University, Stellenbosch 7600, South Africa
2020; Turok \& Visagie, 2021). In South Africa, it has been described as an unmasking of the extent to which White South Africans and their descendants continue to benefit from centuries of systemic racialized privileging, so that the materiality of racism can no longer be ignored (Chatterjee et al., 2020; Haffajee, 2020). For example, the structural barriers (including infrastructure, water, food, sanitation, and digital access) to adhere to and survive COVID-19 lockdown restrictions faced by Black communities in township settings have been forced into view unequivocally (Coetzee \& Kagee, 2020; De Groot \& Lemanski, 2021).

While there has been greater articulation of White privilege in the media, it remains to be explored whether the COVID-19 disruption in public life has shifted White South Africans' acknowledgement of structural racism (Salter et al., 2017) and their motivational and behavioral support for social justice (Durrheim \& Dixon, 2018) or whether the pandemic strengthened a culture of paternalistic charity (Jackman, 1994). The distinction between a charity versus social justice motivation for helping is critical in terms of their impact on both human dignity and social inequality: whereas charity is associated with little appreciation for the root cause of a situation and reinforces the dependency of marginalized communities, a justice motivation is borne 
out of a longer-term desire to empower marginalized communities because of the recognition of historical injustice and resulting personal gain (Halabi et al., 2008; Swartz, 2016). Finally, we were uniquely interested in which groupbased emotions, particularly self-focused guilt and/or otherfocused empathic concern, in this context would be associated most strongly with structural reform (Iyer \& Leach, 2008; Vollhardt \& Sinayobye Twali, 2016).

Much has been theorized about White guilt and shame, and whether these self-directed emotions are appropriate responses to legacies of violent racial subjugation and persistent White privilege in post-colonial and post-slavery contexts (Milazzo, 2016; Phyfer et al., 2020; Sullivan, 2014; Vice, 2010). Yet a large body of empirical research in intergroup settings point to collective guilt's association with support for affirmative action policies and efforts at restitution when experienced by members of historically advantaged groups (Doosje et al., 1998; Imhoff et al., 2012; Iyer et al., 2003; Leach et al., 2006; Swim \& Miller, 1999). Shame's scrutiny of the entire self typically renders individuals less able to connect with others' suffering (Eisenberg, 2000; Fourie, et al., 2017a, b; see also Gausel \& Leach, 2011), whereas guilt's association with a sense of responsibility for harmful acts typically motivates repair (Iyer et al., 2004). Because group-based emotions parallel individuallevel emotions (Salice \& Montes Sánchez, 2016), collective guilt has also been associated more strongly with tendencies to apologize and with outgroup reparation support over time than collective shame (Brown \& Cehajic-Clancy, 2008; Brown et al., 2008).

Empathy reflects the natural capacity to (i) understand and (ii) resonate with another's emotional state, coupled with the (iii) desire to contribute to their well-being (Decety et al., 2016). Because these empathy phenomena are dissociable in terms of subjective experience, neural substrates, and behavioral outcomes, they should be distinguished (Decety \& Yoder, 2016). The present research involved the latter aspect, empathic concern, which includes other-oriented feelings of compassion or sympathy for someone suffering (Batson et al., 2015). Unlike personal distress, which is an egoistic motivation to reduce personal aversive feelings, empathic concern is associated with altruistic motivation and resource sharing to reduce others' suffering (Batson et al., 1987).

While empathic concern thus motivates prosocial behavior, various social and psychological factors along with situational motivations influence the extent to which, and towards whom, empathic concern is deployed (Bruneau et al., 2017; Cameron et al., 2016; Fourie et al., 2017b; Zaki, 2014). Moreover, in contexts of asymmetric power dynamics, where advantaged group members benefit from current status arrangements, empathic concern might be insufficient to produce prosocial change (Dixon, Durrheim et al., 2010 and Dixon, Tropp et al., 2010; Saguy \& Kteily, 2014). In the absence of equitable goals and norms, empathic concern in such contexts might serve to mask structural inequality and maintain the status quo (Zaki \& Cikara, 2015). Indeed, the stereotype content model predicts that people respond to social outgroups high in warmth but low in perceived competence or status with paternalistic positivity/pity that legitimizes inequality (Fiske et al., 2007, 2016).

Taken together, here we examined whether the unprecedented COVID-19 hard lockdown conditions fostered greater acknowledgement of continuing structural racism while raising White South Africans' recognition of our implication and shared ethical responsibility for redress as beneficiaries of apartheid injustices (Leach et al., 2013; Rothberg, 2019). We tested the following specific hypotheses.

First, we hypothesized that a nationally representative sample of White South Africans would express greater empathic concern than self-incriminating guilt/shame in response to Black hardship during the 2020 COVID-19 hard lockdown. We had no specific predictions for personal distress, anger, and fear, which we included for comparison purposes.

Second, we predicted that greater acknowledgement of socioeconomic inequality as ingroup privilege during the pandemic would be associated with greater guilt and awareness of historical White privilege (Leach et al., 2002; Powell et al., 2005). Third, we predicted that heightened guilt (vs. empathic concern) and greater perceived historical privilege would predict progressive perceptual (perceived anti-Black structural racism), behavioral (support for redress), and motivational (social justice) intergroup outcomes but would be unassociated with rightwing populist attitudes and unsustainable charity. While existing work investigating both guilt and empathic concern's reparative tendencies are inconclusive (Harth et al., 2008; Iyer et al., 2003), we argued that guilt's association with ingroup responsibility for illegitimate advantage would be more consequential in generating motivational and actual support for restitution than empathic concern (Cehajic-Clancy et al., 2016). Moreover, empathic concern in response to low-status outgroups might be confounded by pity (Fiske et al., 2007). We explored age as another predictor of interest, given that our sample spanned more than one generation.

Finally, in line with the hypothesis that the pandemic served as a natural intervention, we predicted that support for redress and perceptions of anti-Black structural racism would be greater in the direct aftermath of the 2020 COVID-19 hard lockdown compared to similar data collected in 2018. Because of a growing sense of victimhood amongst the South African White minority (Van Zyl-Hermann, 2018), we also examined participants' beliefs about racism directed towards the ingroup ("anti-White racism"; Saguy et al., 2013). Utilizing measures of both perceived 
anti-Black and anti-White racism provides a more accurate reflection of perceived racialized realities and differs from most WEIRD research ( $\mathrm{Rad}$ et al., 2018) examining only anti-Black racism.

\section{Methods}

\section{Participants}

2020 COVID-19 Pandemic An a priori power analysis using G*Power 3.1 (Faul et al., 2007) indicated that 395 participants would be sufficient to detect a small effect $\left(f^{2}=0.02\right)$ at an alpha of 0.05 with $80 \%$ power. We collected data from a national sample of 461 White South Africans between 12 June and 12 July 2020, the direct aftermath of the South African COVID-19 hard lockdown (level 5). ${ }^{1}$ Of these participants, we excluded 61 who failed to respond correctly to an attention check question, leaving 400 participants (age range: 18 to 71 years, $M_{\text {age }}=34.90, S D=11.57 ; 40 \%$ male). The median income bracket of this sample was ZAR11,000ZAR17,999 per month, 86\% identified as Christian, and 62\% obtained some tertiary education.

2018 Pre-pandemic To determine whether (i) perceptions of racism and (ii) support for redress were greater during the pandemic than before, we compared these variables to similar data collected from a national sample of 195 White South Africans during August 2018 (age range: 20 to 74 years, $M_{\text {age }}=39.62, S D=12.12,23 \%$ male). The median income bracket of this sample was ZAR11,000-ZAR17,999 per month, and 54\% obtained some tertiary education. Data was collected as part of a larger study that included additional measures less relevant to the present research question. Part of this study is reported in Fourie and Moore-Berg (2021).

The same panel service was employed to collect both data sets, and 84 respondents (21\%) completed both surveys. Additional details on sampling can be found in the online Supplementary Material. All participants provided informed consent prior to participation.

\section{Procedure and Stimuli}

Participants completed online surveys specific to the South African context. Each survey stipulated that we do not endorse the legitimacy of artificial, historically imposed,

\footnotetext{
1 The survey was completed before the exposure of large-scale COVID-19 corruption of emergency procurement measures in South Africa (Heywood, 2020).
}

racial categories, but that we accept the resultant realities of racialized identities, which continue to provide a context for people's lived experiences. We furthermore indicated that, unless specified otherwise, the word "Black" was used inclusively, referring to all persons of color who were disempowered during apartheid.

\section{COVID-19 Pandemic Measures}

Affective Responses to the Pandemic These items captured affective responses to the plight of Black individuals during the COVID-19 pandemic. Participants were asked "When considering the hardships of Black South Africans, what kinds of feelings did the current pandemic evoke for you?" for each of 6 different emotions on slider scales from 1 (not at all) to 9 (very much). Emotion items included compassion (empathic concern), guilt, shame, anger, fear, and personal distress. Empathic concern was operationalized as compassion to ensure that participants understood its meaning (Fourie et al., 2019; Zaki \& Cikara, 2015).

COVID-19 Observations of Inequality Seven questions probed participants' general observations regarding socioeconomic inequality and the experiences of a relatively privileged White minority compared to a largely disadvantaged Black majority during the COVID-19 pandemic (see Supplementary Material). For example, participants were asked whether they agree with statements such as "During the current COVID-19 hard lockdown, White people had better access to medical facilities and essential services than Black people" and "Black people were more dependent on the distribution of food parcels than White people" on a scale ranging from 1 (not at all) to 9 (very much) $(\alpha=0.93)$. Higher scores indicated greater acknowledgement of socioeconomic inequality.

Perceptions of Historical Privilege Five questions assessed participants' current awareness of being White and privileged, thus having benefited historically from apartheid injustices (see Supplementary Material). In this way, we assessed perceptions of implication arising from gross human rights abuses, specifically that of being a beneficiary (Rothberg, 2019). For example, participants were asked to indicate whether they agreed with statements such as "I have benefitted economically from apartheid: The inheritance I receive (will receive) from my parents is based on pre-1994 benefits" and "My children will continue to benefit economically from the injustices of apartheid" on a scale ranging from 1 (strongly disagree) to 7 (strongly agree; $\alpha=0.76$ ).

Perceptions of Racism To assess perceptions of interpersonal and structural racism, we asked participants "How 
much did/does each form of racism affect Black African ${ }^{2}$ people in South Africa" (anti-Black racism) at two time points: during apartheid and today, and "How much does each form of racism affect White people today" (anti-White racism), on continuous sliders ranging from 1 (not at all) to 100 (very much; adapted from Rucker et al., 2019). To ensure that participants understood the distinction between these terms, interpersonal racism was defined as "negative attitudes and discriminatory behaviors by individuals towards members of specific racial groups," whereas structural racism was defined as "institutional practices and structural factors (e.g., laws, policies) that routinely disadvantage specific racial groups."

While we acknowledge that the term racism should be reserved for race-based oppression along historically institutionalized power dimensions, we examined perceptions of anti-White racism to gain a better understanding of White participants' perceptions of feeling oppressed (i.e., victimhood).

Support for Redress (Behavior) To assess support for realworld outcomes that will have a positive impact on historically marginalized individuals and communities in South Africa, participants were given the opportunity to sign five purportedly real petitions urging government to implement progressive policies. These included support towards a wealth tax for the $10 \%$ wealthiest citizens, Black Economic Empowerment legislation, Affirmative Action legislation, free tertiary education for previously disadvantaged students, and land expropriation policies (Dixon, Durrheim et al., 2010 and Dixon, Tropp et al., 2010; see Supplementary Material). For each petition, participants indicated whether they wanted to add their signature to the petition (coded as 1), to a counter-petition (coded as -1 ), or to neither (coded as $0 ; \alpha=0.84$ ). Using these codes, we created an average index of support for redress for each participant.

Prosocial Motivation Participants were asked to indicate whether they have contributed personally towards relief measures for Black South Africans during the COVID-19 lockdown in terms of time or money (yes or no). Those who responded affirmatively were then asked to indicate what motivated their prosocial behavior on continuous sliders ranging from 1 (not at all) to 100 (very much; see Supplementary Material). Three items assessed charity motivation, for example, "It is my calling as a good person to assist the most vulnerable in society" $(\alpha=0.58)$, and three items assessed social justice motivation, or a sense of moral responsibility for redress, for example, "I have helped

\footnotetext{
${ }^{2}$ Here we assessed perceptions about racism regarding Black Africans, as the majority racial outgroup in South Africa.
}

because the unequal impact of the pandemic is largely shaped by our apartheid history" $(\alpha=0.84)$.

Right-Wing Attitudes To assess right-wing attitudes, participants were asked to indicate their agreement with six questions tapping into populist narratives presented in the media during the 2020 pandemic (see Supplementary Material). For example, participants were asked to indicate their agreement with statements such as "The government has abused COVID-19 to boost their own racist agenda and control White people", and "During the pandemic, it has once again been up to predominantly White institutions (e.g., White churches, AfriForum) to alleviate the distress of the poor," on slider scales ranging from 1 (not at all) to 9 (very much; $\alpha=0.85$ ).

\section{Pre-pandemic Measures}

Perceptions of Racism The 2018 instrument used to assess participants' perceptions about the impact of interpersonal and structural forms of racism against Black people (during apartheid and today) and against White people (today) was the same as that used during the 2020 COVID-19 pandemic. These data are reported in Fourie and Moore-Berg (2021).

Support for Redress (Behavior) The 2018 petition instrument assessed support/opposition for the same five measures of redress used in the 2020 COVID-19 pandemic survey. Because the petitions were framed inversely, i.e., whether participants supported policies that will have a negative impact on Black people, data from these petitions were first reverse scored and then averaged to create an index of support for redress (see Supplementary Material).

\section{Results}

\section{COVID-19 Pandemic Data}

To test our first hypothesis, we conducted a repeated measures ANOVA on the emotion items, which indicated that there were significant differences in the strength of reported emotions, $F(4.09,1633.68)=70.42, p<0.001, \eta_{p}^{2}=0.15$, $\varepsilon=0.82 .{ }^{3}$ Confirming our hypothesis, planned contrasts indicated that empathic concern $(M=6.34, S D=2.33)$ was rated as significantly higher than all other emotions ( $p$ s $<0.001, r \mathrm{~s}>0.37)$. Guilt $(M=4.35, S D=2.54)$ was rated

\footnotetext{
${ }^{3}$ Because the assumption of sphericity was violated, we adjusted the degrees of freedom using a Greenhouse-Geisser epsilon correction.
} 
Table 1 Zero-order correlations between 2020 COVID-19 observations of inequality and historical privilege, guilt, shame, empathic concern, anger, fear, and personal distress $(N=400)$

\begin{tabular}{llllllll}
\hline & Historical privilege & Guilt & Shame & Empathic concern & Anger & Fear & Personal distress \\
\hline COVID-19 inequality & $.58^{* * *}$ & $.46^{* * *}$ & $.45^{* * *}$ & $.18^{* *}$ & $.17 * *$ & $.12^{*}$ & .07 \\
$M$ & 4.44 & 4.35 & 4.08 & 6.34 & 4.75 & 5.12 & 5.15 \\
SD & 1.34 & 2.54 & 2.52 & 2.33 & 2.58 & 2.58 & 2.58 \\
Quartiles & $3.4,4.4,5.6$ & $2,5,6$ & $2,4,6$ & $5,7,8.8$ & $2.3,5,7$ & $3,5,7$ & $3,5,7$ \\
\hline
\end{tabular}

${ }^{*} p<.05 . * * p<.01 . * * * p<.001$

as significantly lower than all emotions ( $p \mathrm{~s}<0.01, r \mathrm{~s}>0.15$ ), except shame $(M=4.08, S D=2.52)$, which was rated the lowest ( $p=0.001, r=0.16$ ). Interestingly, empathic concern was positively associated with age $(r=0.14, p=0.004)$, whereas guilt was negatively associated with age $(r=-0.16$, $p=0.001)$. No other emotions were significantly associated with age.

Next, we examined the hypothesis that observations of socioeconomic inequality, as it unfolded during the COVID19 lockdown, would be associated with a heightened awareness of historical privilege, as well as guilt in response to Black hardship (see Table 1 for zero-order correlations and descriptive statistics). As expected, greater acknowledgement of socioeconomic inequality during the pandemic was strongly associated with an awareness of historical privilege, as well as with guilt and shame $(r \mathrm{~s}>0.45, p s<0.001)$. COVID-19 observations of inequality were also positively, but modestly, associated with empathic concern and anger ( $r \mathrm{~s}>0.17, p \mathrm{~s}<0.01)$, and marginally with fear and personal distress $(p s>0.02) .{ }^{4}$ The difference in strength of correlations between COVID-19 observations of inequality and guilt, and between COVID-19 observations of inequality and empathic concern, was significant, Steiger's $z=4.99$, $p<0.001$.

To gain insight into how well perceived historical privilege and affective responses (particularly guilt and empathic concern) during the pandemic predicted outcome measures, we performed regression analyses. ${ }^{5}$ Descriptive statistics and intercorrelations of these variables are presented in Table 2, with simultaneous regressions for each outcome measure presented in Table 3.

Results of these analyses consistently showed the impact of greater perceived historical privilege and greater guilt,

\footnotetext{
4 To limit the number of correlations (Curtin \& Schulz, 1998), only correlations significant at the $1 \%$ level (i.e., $p<.01$ ) were interpreted and further inspected using 95\% confidence intervals (CIs) derived through bootstrapping.

5 We omitted fear and personal distress from these models as they did not contribute significantly towards explaining the variance of any dependent variables.
}

which were also positively associated $(r=0.28, p<0.001)$, in predicting higher responses on progressive outcome measures: perceptions of anti-Black structural (and interpersonal) racism today ( $\beta \mathrm{s}>0.28, p \mathrm{~s}<0.001)$, support for redress $(\beta \mathrm{s}>0.25, p \mathrm{~s}<0.001)$, and social justice motivation $(\beta \mathrm{s}>0.32, p \mathrm{~s}<0.001)$. Perceived historical privilege and guilt furthermore predicted reduced right-wing attitudes $(\beta \mathrm{s}>-0.16, p \mathrm{~s}<0.002)$ and reduced perceptions of antiWhite structural (and interpersonal) racism $(\beta \mathrm{s}>-0.18$, $p s<0.01)$. These results could not be explained by shame, as guilt contributed unique variance even after controlling for shame (see Table 3).

Anger was related most significantly to greater right-wing attitudes and increased perceptions of anti-White structural (and interpersonal) racism $(\beta \mathrm{s}>0.24, p \mathrm{~s}<0.001)$, which suggests that it stemmed from a reactionary focus on perceived ingroup disadvantage, rather than on systemic outgroup injustices during the pandemic (Leach et al., 2006). Adding age as an additional predictor of interest did not change existing results but showed that younger age was associated significantly with more progressive outcomes: greater perceptions of anti-Black structural racism and greater support for redress $(\beta \mathrm{s}>-0.12, p \mathrm{~s}<0.01)$, as well as reduced right-wing attitudes and reduced perceptions of anti-White structural racism $(\beta \mathrm{s}>0.12, p \mathrm{~s}=0.01$; see Supplementary Table S1).

Of significance is that empathic concern was neither associated with perceived historical privilege ( $r=0.04$, $p=0.46$ ), nor predicted any progressive outcome measures significantly $(p s>0.10)$. Instead, empathic concern significantly predicted only charity motivation $(\beta=0.16$, $p=0.02$ ). It should be noted that a charity motivation was dominant in the 199 participants who indicated that they have contributed towards emergency relief: only 33\% agreed strongly with a social justice motivation for giving, while $63 \%$ agreed strongly with a charity motivation for giving (Fig. 1).

Although guilt was thus not experienced most prominently (cf. Swim \& Miller, 1999), together with historical privilege, it was most strongly associated with observations of socioeconomic inequality during the pandemic, 


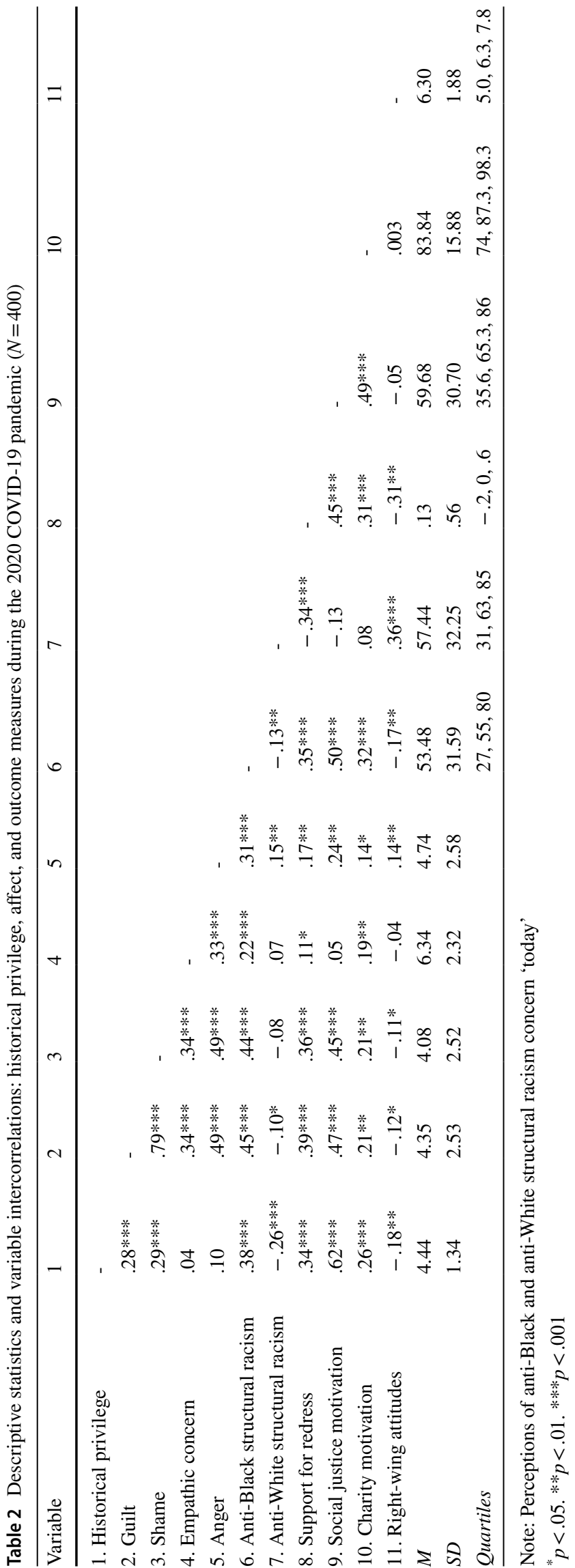

and the only affective response significantly predicting progressive perceptual, behavioral, and motivational outcome measures.

\section{Comparison with 2018 Pre-pandemic Data}

To test our final hypothesis, we compared (i) perceptions of racism today and (ii) support for redress following the 2020 COVID-19 lockdown to similar data collected during 2018. While these samples were only partially matched, observing significant progressive changes would provide at least partial support for our hypothesis that the pandemic served as a natural intervention.

As in 2018, participants perceived interpersonal racism today $(M=56.49, S D=30.29)$ to have a greater impact than structural racism today $(M=53.48, S D=31.59)$ on Black people during the 2020 COVID-19 pandemic, $t(397)=2.84$, $p=0.005, d=0.10$. In stark contrast to the 2018 sample, however, where perceptions of anti-White racism today were exceedingly high, participants did not perceive significant differences in either structural or interpersonal racism experienced by Black and White people today during the pandemic, $t \mathrm{~s}<1.8, p \mathrm{~s}>0.15, d \mathrm{~s}<0.10$ (Fig. 2). Moreover, perceptions of structural and interpersonal racism experienced by Black people today were significantly higher during the pandemic than in 2018 (anti-Black structural racism $M_{\text {diff }}=15.80$, anti-Black interpersonal racism $M_{\text {diff }}=9.75$, $t \mathrm{~s}>3.67, p \mathrm{~s}<0.001, d \mathrm{~s}>0.30$ ), whereas perceptions of anti-White structural and interpersonal racism during the pandemic were significantly lower than in 2018 (anti-White structural racism $M_{\text {diff }}=-18.02$, anti-White interpersonal racism $\left.M_{\text {diff }}=-17.37, t \mathrm{~s}>6.60, p \mathrm{~s}<0.001, d \mathrm{~s}>0.54\right)$. White participants following the 2020 COVID-19 lockdown thus showed greater acknowledgement of structural and interpersonal racism experienced by Black people today, coupled with reduced perceptions of anti-White structural and interpersonal racism today, than those in 2018. These changes suggest that notions of White people as a racially oppressed minority (i.e., White victimhood) in South Africa were less salient immediately following the 2020 COVID-19 lockdown.

Regarding support for redress, we also compared petition data for the 2020 sample to that obtained in 2018. Chisquare analysis indicated that support for redress for each of the five petitions was much more robust following the 2020 COVID-19 lockdown than during $2018\left(\chi^{2}>39.00\right.$, $p$ s $<0.001$; Table 4). Moreover, the average support for redress score was significantly greater during the pandemic than in 2018 (Mann-Whitney $U=57,665.50, p<0.001$; Fig. 3). These data suggest that White participants were much more inclined to support economic policies of redress in the immediate aftermath of the COVID-19 pandemic than towards the end of 2018. 
Table 3 Simultaneous regressions predicting outcome measures as a function of historical privilege and affect during the 2020 COVID-19 pandemic $(N=400)$

\begin{tabular}{|c|c|c|c|c|c|c|c|c|c|c|c|c|}
\hline & \multicolumn{2}{|c|}{$\begin{array}{l}\text { Anti-Black } \\
\text { structural racism } \\
\left(R^{2}=.29\right)^{\mathrm{a}}\end{array}$} & \multicolumn{2}{|c|}{$\begin{array}{l}\text { Anti-White } \\
\text { structural racism } \\
\left(R^{2}=.12\right)^{\mathrm{a}}\end{array}$} & \multicolumn{2}{|c|}{$\begin{array}{l}\text { Support for redress } \\
\left(R^{2}=.21\right)\end{array}$} & \multicolumn{2}{|c|}{$\begin{array}{l}\text { Social justice moti- } \\
\text { vation }\left(R^{2}=.50\right)\end{array}$} & \multicolumn{2}{|c|}{$\begin{array}{l}\text { Charity } \\
\text { motivation } \\
\left(R^{2}=.12\right)\end{array}$} & \multicolumn{2}{|c|}{$\begin{array}{l}\text { Right-wing atti- } \\
\text { tudes }\left(R^{2}=.09\right)\end{array}$} \\
\hline & $\beta$ & $p$ & $\beta$ & $p$ & $\beta$ & $p$ & $\beta$ & $p$ & $\beta$ & $p$ & $\beta$ & $p$ \\
\hline Historical privilege & .29 & $<.001$ & -.23 & $<.001$ & .25 & $<.001$ & .54 & $<.001$ & .24 & .001 & -.16 & .002 \\
\hline Guilt & $.28^{\mathrm{b}}$ & $<.001$ & $-.18^{\mathrm{b}}$ & $<.01$ & $.33^{\mathrm{c}}$ & $<.001$ & $.32^{\mathrm{c}}$ & $<.001$ & .10 & .16 & -.19 & .001 \\
\hline Empathic concern & .08 & .10 & .06 & .23 & -.01 & .87 & -.03 & .55 & .16 & .02 & -.06 & .30 \\
\hline Anger & .12 & .02 & .24 & $<.001$ & -.01 & .86 & .08 & .16 & .03 & .66 & .26 & $<.001$ \\
\hline
\end{tabular}

Note: Perceptions of anti-Black and anti-White structural racism concern 'today'. Regression analyses for social justice and charity motivation were performed on a subset of participants $(n=199)$, who indicated that they have contributed personally towards relief measures during the COVID-19 pandemic

${ }^{a}$ Similar regression results are obtained for perceptions of interpersonal racism

${ }^{\mathrm{b}}$ Indicates an estimate that is significant at $p<.05$ controlling for shame

${ }^{\mathrm{c}}$ Indicates an estimate that is significant at $p<.01$ controlling for shame

Social Justice Motivation Charity Motivation

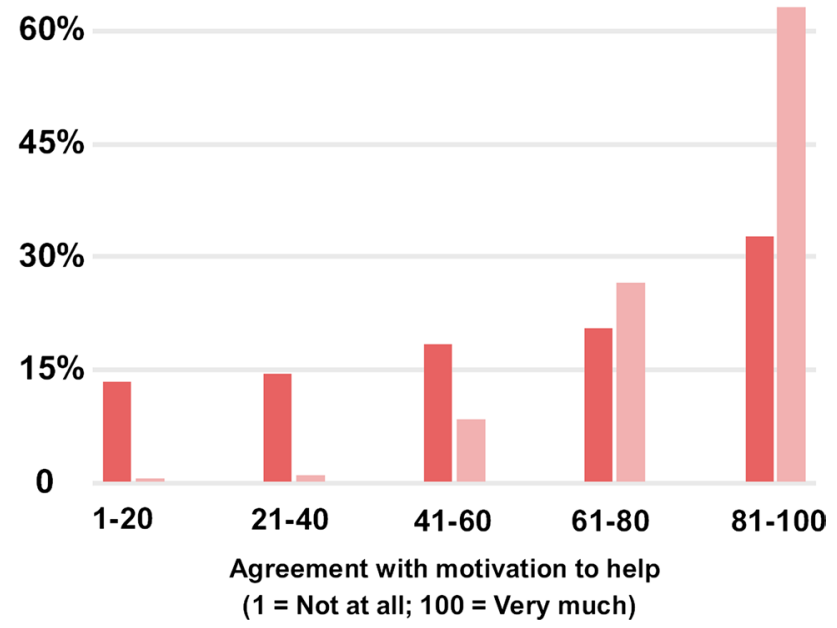

Fig. 1 Social justice versus charity motivation to contribute towards emergency relief measures during the 2020 COVID-19 lockdown. Data are from 199 participants who indicated that they have contributed personally

\section{Discussion}

The present research examined whether White South Africans' perceptions of continuing structural injustice and support for redress were encouraged through greater awareness of historical privilege and guilt experienced during the COVID-19 pandemic. Our data suggest that the pandemic and its societal impact served as a natural intervention: not only were observations of socioeconomic inequality during the pandemic associated strongly with perceived historical privilege and with guilt, but White acknowledgement of structural racism and support for economic redress were also greater in the immediate aftermath of hard lockdown compared to 2018. Although empathic concern for Black hardship was evoked most saliently, guilt together with perceived historical privilege consistently predicted greater progressive outcomes (perceived anti-Black structural racism, support for policies of redress, and social justice motivation), and reduced ultra-conservative perspectives (right-wing attitudes and perceptions of anti-White racism). By contrast, empathic concern predicted only charity motivation. These findings raise several questions for discussion and future research.

First, what was it about the pandemic that potentially raised awareness of racialized privilege and support for redress? We believe the unprecedented conditions of lockdown, which highlighted stark material discrepancies, provided a visceral confrontation with continuing structural racism and a unique opportunity to reflect on unearned privileges based on generations of racial discrimination. The pandemic thus served to bring the past into the present, which likely contributed significantly towards eliciting collective self-critical feelings of guilt (Leach et al., 2013). The fact that the pandemic was a "natural" intervention is also significant. In contrast to political intergroup interventions, where a focus on gross human rights violations is explicit (Fourie et al., 2013), the pandemic's exposure of unjust racialized inequalities was more indirect, less threatening, allowing more room for self-critical group-based emotions to surface. The South African Truth and Reconciliation Commission process, for example, tended to conflate guilt with a legalistic, individualistic understanding of "criminal guilt," which arguably undermined more collective feelings of wrongdoing (Swart, 2017; Verwoerd, 1999).

Second, how can we understand younger age's association with heightened guilt, more progressive outcomes, 
Fig. 2 Perceptions about the impact of interpersonal and structural forms of racism on Black and White people (anti-Black and anti-White racism, respectively) during apartheid and today. Panel a represents data collected from a comparable sample of White South Africans during August 2018 (Fourie \& Moore-Berg, 2021), while panel b represents data collected following the 2020 COVID-19 hard lockdown. Error bars represent 95\% confidence intervals $(\mathrm{CI})$. $* * * p<.001$

Interpersonal racism

a) $2018(N=195)$

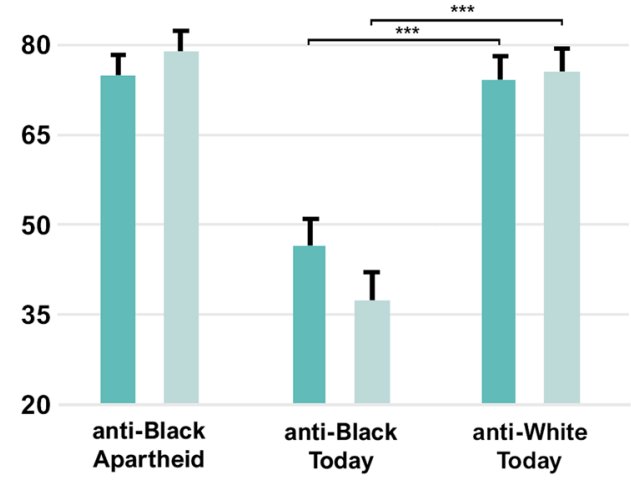

Structural racism

b) $\operatorname{CovID-19}(N=400)$

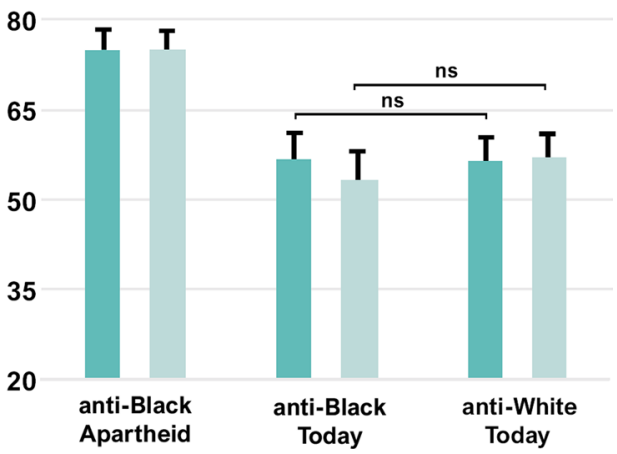

Table 4 Support for redress: responses to petitions urging government to implement progressive economic policies in 2018 and during the 2020 COVID-19 pandemic

\begin{tabular}{|c|c|c|c|c|c|}
\hline \multirow[t]{2}{*}{ Petitions } & & \multicolumn{2}{|c|}{$\begin{array}{l}2018 \\
(N=195)\end{array}$} & \multicolumn{2}{|c|}{$\begin{array}{l}\text { COVID-19 } \\
(N=400)\end{array}$} \\
\hline & & Count & $\%$ & Count & $\%$ \\
\hline \multirow[t]{3}{*}{ Wealth tax } & Oppose & 97 & 49.7 & 45 & 11.3 \\
\hline & Neither & 66 & 33.8 & 170 & 42.8 \\
\hline & Support & 32 & 16.4 & 182 & 45.8 \\
\hline \multirow{3}{*}{$\begin{array}{l}\text { Black economic empower- } \\
\text { ment }\end{array}$} & Oppose & 116 & 59.5 & 107 & 27.0 \\
\hline & Neither & 53 & 27.2 & 174 & 43.8 \\
\hline & Support & 26 & 13.3 & 116 & 29.2 \\
\hline \multirow[t]{3}{*}{ Free tertiary education } & Oppose & 68 & 34.9 & 65 & 16.4 \\
\hline & Neither & 86 & 44.1 & 159 & 40.1 \\
\hline & Support & 41 & 21.0 & 173 & 43.6 \\
\hline \multirow[t]{3}{*}{ Affirmative action } & Oppose & 122 & 62.6 & 82 & 20.7 \\
\hline & Neither & 52 & 26.7 & 173 & 43.6 \\
\hline & Support & 21 & 10.8 & 142 & 35.8 \\
\hline \multirow[t]{3}{*}{ Land expropriation } & Oppose & 132 & 67.7 & 141 & 35.5 \\
\hline & Neither & 38 & 19.5 & 170 & 42.8 \\
\hline & Support & 25 & 12.8 & 86 & 21.7 \\
\hline
\end{tabular}

Note: \% Support highlighted in bold face

reduced right-wing attitudes, and reduced perceptions of anti-White racism? These results follow an international trend, where the self-critical engagement with past immoral actions emerge more strongly amongst 2 nd and 3rd postwar generations (Branscombe \& Doosje, 2004). Because younger White South Africans have no causal responsibility for apartheid atrocities and its legacies as members of "perpetrator" or "participant" generations (Govier \& Verwoerd, 2011), the acceptance of being implicated beneficiaries is less threatening legally, morally, and emotionally (Rothberg, 2019). Hence, they are potentially more likely to admit feelings of guilt and provide restitution than older generations.

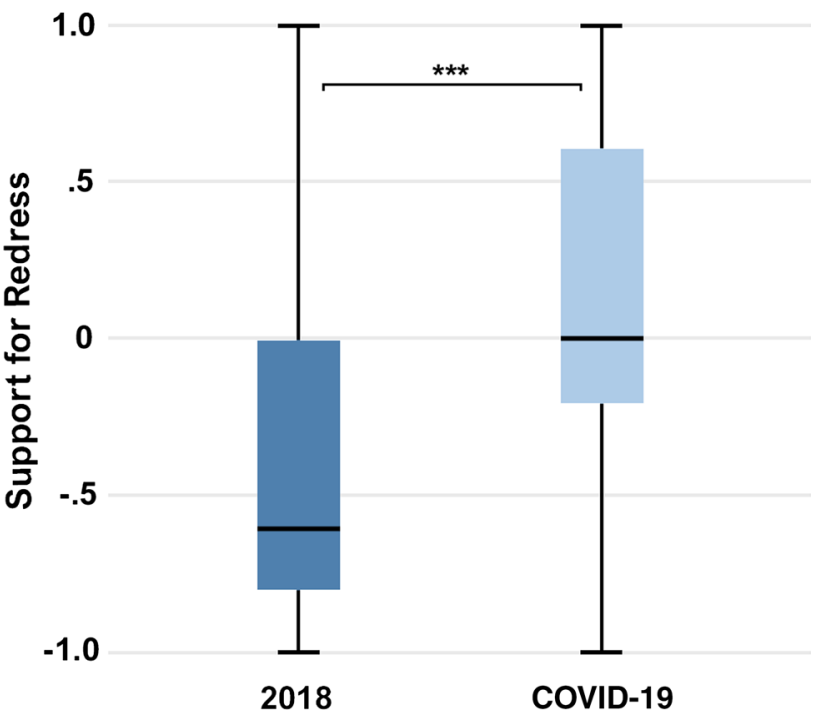

Fig. 3 Boxplots indicating support for policies of redress in South Africa during $2018(N=195)$ and following the 2020 COVID-19 hard lockdown $(N=400)$. Data were averaged for 5 petitions where participants indicated support (coded as 1 ), opposition (coded as -1 ), or neither (coded as 0$) . * * * p<.001$

Their group identification might also be less cemented than pre-1994 generations, who were conditioned by a militarized, sanctified "anti-Communist" Whiteness (Verwoerd \& Edlmann, 2021). Some evidence suggests that a weaker group identification enables stronger guilt and motivation for repair (Doosje et al., 2006; Powell et al., 2005).

Third, why was empathic concern and charity motivation evoked most saliently and why is this so problematic in the South African context? Faced with vivid, distressing, media images of Black people queuing for food, it is much easier to interpret large-scale hunger as a humanitarian crisis and respond with compassion and potentially short-lived (remote) help (Hunt et al., 2006; Västfjäll et al., 2014), which do not imply responsibility (Meerholz et al., 
2019), than to face the dysphoria of guilt and moral implication in apartheid as crime against humanity ( $\mathrm{Xu}$ et al., 2011). Indeed, empathic concern in response to Black hardship was entirely unrelated to perceived historical privilege in our sample. Moreover, charity strengthens a positive self-image as a "good person" and, especially, a "good White" (Jones, 2004). While we accept that in a crisis charity is better than indifference, the racialized nature of this charity, especially as Christian missionary outreaches, encourages a paternalistic "savior mentality" protecting Whiteness (Bowers du Toit \& Nkomo, 2014).

The above interpretation helps to explain empathic concern's weak association with outcome measures that will contribute to structural reform. In addition, we are drawn to the possibility that participants' empathic concern responses more accurately reflected pity towards impoverished Black South Africans, a related but conceptually distinct construct (Boleyn-Fitzgerald, 2003). People typically feel worse when misfortunes befall pitied targets (social outgroups high in social warmth but low in status) than ingroup targets (Cikara \& Fiske, 2011). Moreover, pitied targets are often the recipients of active helping (e.g., charity), but also passive harm (e.g., neglect; Fiske et al., 2007). To the extent that charity-as-White-pity contributes to the perpetuation of systemic racism, more than passive harm is at stake, however.

Fourth, we need to examine critically the data's suggestion that White guilt holds promise in contributing to structural reform. Criticisms against the expression of White guilt include its association with 'virtue signaling' (Phyfer et al., 2020) and selfish relief from incriminatory feelings (Batson, 1998; Iyer et al., 2003), rather than with genuine other-directed behaviors to transform social injustices. While public displays of guilt may certainly be unproductive, we believe the present anonymous, private conditions of data collection mitigated against the pitfalls of White guilt becoming a public performance, placing undue pressure on Black people to respond (typically through forgiveness). We also agree that an exclusive focus on White guilt as an individual emotional state is insufficient to disrupt the structural systems that sustain and perpetuate racial inequality (Milazzo, 2016; Moore, 2019).

Nevertheless, we are encouraged that our data is supported by substantial previous research observing that advantaged groups' collective experiences of guilt provide the impetus for social redress, as it "marks what concerns us, still, in spite of all rationalization or denial" (Cehajic-Clancy et al., 2016; Prade-Weiss, 2020, p. 8; Vollhardt \& Sinayobye Twali, 2016). Indeed, for those participants who contributed towards relief measures during the pandemic, feelings of guilt strongly predicted a social justice, rather than a charity motivation for helping. Guilt in this context might therefore be understood as emanating not only from the collective misdeeds of group members in the past, but also from the acceptance of and continuous enjoyment of unearned material benefits in the present, especially during lockdown.

Finally, we concur that by itself, guilt is either too fleeting and infrequent (Iyer et al., 2004; Leach et al., 2013), or too ruminative and maladaptive when chronic self-blame focuses attention inward (Harder, 1995), to bring about lasting change. With the easing of lockdown conditions, evidence emerged that neither increased empathic concern and charity nor changes in political awareness and historical responsibility associated with guilt are likely to be sustained (Hamann, 2020). We contend that for genuine empathic concern and guilt to become "unsettling" beyond the immediate crisis (Krondorfer, 2015), these other-oriented and self-critical feelings need to be combined with the deliberate cultivation of capacities through intrapersonal/intergroup relational processes within contexts supporting equitable goals. Only then will their motivational push translate into sustainable commitments to promote social justice.

Acknowledgements We thank our colleagues at Historical Trauma and Transformation for the rich conversations from which this research emerged.

\section{Additional Information}

Funding This work was supported by a grant MF received for COVID19 related research from the Vice-Rector (RIPS) fund, Stellenbosch University.

Conflict of Interest The authors declare no competing interests.

Data Availability The data that support the findings of this study are openly available at Open Science Framework, https://osf.io/62qag/.

Ethical Approval This research has been approved by the University of Stellenbosch's Humanities Research Ethics Committee and the research was performed to ethical standards as laid down in the 1964 Declaration of Helsinki.

Consent to Participate All participants provided informed consent to take part in this research.

Consent for Publication All participants provided consent to publish the findings of this research.

Supplementary Information The online version contains supplementary material available at https://doi.org/10.1007/s42761-021-00073-7.

Author Contributions M.M.F. and W.J.V. conceptualized the research. M.M.F. collected and analyzed all data and wrote and prepared the main manuscript text (including figures). W.J.V. assisted with data interpretation and co-wrote the Discussion. Both authors approved the submitted version of the manuscript. 


\section{References}

Batson, C. D. (1998). Altruism and prosocial behavior. In D. T. Gilbert, S. T. Fiske, \& G. Lindzey (Eds.), The handbook of social psychology (Vol. 2, pp. 282-316). McGraw-Hill.

Batson, C. D., Fultz, J., \& Schoenrade, P. A. (1987). Distress and empathy: Two qualitatively distinct vicarious emotions with different motivational consequences. Journal of Personality, 55(1), 19-39. https://doi.org/10.1111/j.1467-6494.1987.tb00426.x

Batson, C. D., Lishner, D. A., \& Stocks, E. L. (2015). The empathy-altruism hypothesis. In D. A. Schroeder \& W. G. Graziano (Eds.), The Oxford handbook of prosocial behavior (pp. 259-281). Oxford University Press.

Boleyn-Fitzgerald, P. (2003). Care and the problem of pity. Bioethics, 17(1), 1-20. https://doi.org/10.1111/1467-8519.00318

Bottan, N., Hoffmann, B., \& Vera-Cossio, D. (2020). The unequal impact of the coronavirus pandemic: Evidence from seventeen developing countries. PLOS ONE, 15(10), e0239797. https://doi. org/10.1371/journal.pone.0239797

Bowers du Toit, N. F., \& Nkomo, G. (2014). The ongoing challenge of restorative justice in South Africa: How and why wealthy suburban congregations are responding to poverty and inequality. HTS Theological Studies, 70, 01-08.

Branscombe, N. R., \& Doosje, B. (2004). Collective guilt: International perspectives. Cambridge University Press.

Brown, R., \& Cehajic-Clancy, S. (2008). Dealing with the past and facing the future: Mediators of the effects of collective guilt and shame in Bosnia and Herzegovina. European Journal of Social Psychology, 38, 669-684. https://doi.org/10.1002/ejsp.466

Brown, R., González, R., Zagefka, H., Manzi, J., \& Čehajić, S. (2008). Nuestra culpa: Collective guilt and shame as predictors of reparation for historical wrongdoing. Journal of Personality and Social Psychology, 94(1), 75-90. https://doi.org/10.1037/ 0022-3514.94.1.75

Bruneau, E. G., Cikara, M., \& Saxe, R. (2017). Parochial empathy predicts reduced altruism and the endorsement of passive harm. Social Psychological and Personality Science, 8(8), 934-942. https://doi.org/10.1177/1948550617693064

Cameron, C. D., Harris, L. T., \& Payne, B. K. (2016). The emotional cost of humanity: Anticipated exhaustion motivates dehumanization of stigmatized targets. Social Psychological and Personality Science, 7(2), 105-112. https://doi.org/10.1177/19485 50615604453

Cehajic-Clancy, S., Goldenberg, A., Gross, J., \& Halperin, E. (2016). Social-psychological interventions for intergroup reconciliation: An emotion regulation perspective. Psychological Inquiry, 27, 73. https://doi.org/10.1080/1047840X.2016.1153945

Chatterjee, A. (2019). Measuring wealth inequality in South Africa: An agenda. Development Southern Africa, 36(6), 839-859. https://doi.org/10.1080/0376835X.2019.1690977

Chatterjee, A., Gethin, A., \& Czajka, L. (2020). Coronavirus: Why South Africa needs a wealth tax now. The Conversation. https://theconversation.com/coron avirus-why-south-africa-needs-a-wealth-tax-now-137283.

Cikara, M., \& Fiske, S. T. (2011). Bounded empathy: Neural responses to outgroup targets' (mis)fortunes. Journal of Cognitive Neuroscience, 23(12), 3791-3803. https://doi.org/10.1162/ jocn_a_00069

Coetzee, B. J. S., \& Kagee, A. (2020). Structural barriers to adhering to health behaviours in the context of the COVID-19 crisis: Considerations for low- and middle-income countries. Global Public Health, 15(8), 1093-1102https://doi.org/10.1080/17441 692.2020 .1779331

Curtin, F., \& Schulz, P. (1998). Multiple correlations and Bonferroni's correction. Biological Psychiatry, 44(8), 775-777.
De Groot, J., \& Lemanski, C. (2021). COVID-19 responses: Infrastructure inequality and privileged capacity to transform everyday life in South Africa. Environment and Urbanization, 33(1), 255-272. https://doi.org/10.1177/0956247820970094

Decety, J., Bartal, I.B.-A., Uzefovsky, F., \& Knafo-Noam, A. (2016). Empathy as a driver of prosocial behaviour: Highly conserved neurobehavioural mechanisms across species. Philosophical Transactions of the Royal Society of London Series b, Biological Sciences, 371(1686), 20150077-20150077. https://doi.org/10. 1098/rstb.2015.0077

Decety, J., \& Yoder, K. J. (2016). Empathy and motivation for justice: Cognitive empathy and concern, but not emotional empathy, predict sensitivity to injustice for others. Social Neuroscience, 11(1), 1-14. https://doi.org/10.1080/17470919.2015.1029593

Dixon, J., Durrheim, K., Tredoux, C. G., Tropp, L. R., Clack, B., Eaton, L., \& Quayle, M. (2010). Challenging the stubborn core of opposition to equality: Racial contact and policy attitudes. Political Psychology, 31(6), 831-855. https://doi.org/10.1111/j.1467-9221. 2010.00792.x

Dixon, J., Tropp, L. R., Durrheim, K., \& Tredoux, C. (2010). "Let them eat harmony": Prejudice-reduction strategies and attitudes of historically disadvantaged groups. Current Directions in Psychological Science, 19(2), 76-80. https://doi.org/10.1177/09637 21410363366

Doosje, B., Branscombe, N., Spears, R., \& Manstead, A. (2006). Antecedents and consequences of group-based guilt: The effects of ingroup identification. Group Processes \& Intergroup Relations, 9(3), 325-338. https://doi.org/10.1177/1368430206064637

Doosje, B., Branscombe, N. R., Spears, R., \& Manstead, A. S. R. (1998). Guilty by association: When one's group has a negative history. Journal of Personality and Social Psychology, 75(4), 872-886. https://doi.org/10.1037/0022-3514.75.4.872

Durrheim, K., \& Dixon, J. (2018). Intergroup contact and the struggle for social justice. In P. L. H. Jr. (Ed.), Oxford handbook of social psychology and social justice. Oxford, United Kingdom: Oxford University Press.

Eisenberg, N. (2000). Emotion, regulation and moral development. Annual Review of Psychology, 51, 665-697. https://doi.org/10. 1146/annurev.psych.51.1.665

Faul, F., Erdfelder, E., Lang, A.-G., \& Buchner, A. (2007). G*Power 3: A flexible statistical power analysis program for the social, behavioral, and biomedical sciences. Behavior Research Methods, 39(2), 175-191. https://doi.org/10.3758/BF03193146

Fiske, S. T., Cuddy, A. J. C., \& Glick, P. (2007). Universal dimensions of social cognition: Warmth and competence. Trends in Cognitive Sciences, 11(2), 77-83. https://doi.org/10.1016/j.tics.2006.11.005

Fiske, S. T., Dupree, C. H., Nicolas, G., \& Swencionis, J. K. (2016). Status, power, and intergroup relations: The personal is the societal. Current Opinion in Psychology, 11, 44-48. https://doi.org/ 10.1016/j.copsyc.2016.05.012

Fourie, M. M., Gobodo-Madikizela, P., \& Stein, D. J. (2013). Empathy and forgiveness in South Africa: The Truth and Reconciliation Commission. In M. Linden \& K. Rutkowski (Eds.), Hurting memories and beneficial forgetting (pp. 227-240). Elsevier Inc.

Fourie, M. M., \& Moore-Berg, S. L. (2021). We cannot empathize with what we cannot recognize: Perceptions of structural versus interpersonal racism. Manuscript submitted for publication.

Fourie, M. M., Stein, D. J., Solms, M., Gobodo-Madikizela, P., \& Decety, J. (2017a). Empathy and moral emotions in post-apartheid South-Africa: An fMRI investigation. Social Cognitive and Affectice Neuroscience. https://doi.org/10.1093/scan/nsx019

Fourie, M. M., Subramoney, S., \& Gobodo-Madikizela, P. (2017b). A less attractive feature of empathy: Intergroup empathy bias. In M. Kondo (Ed.), Empathy: An evidence-based interdisciplinary perspective (pp. 45-61): InTech. ISBN 978-953-51-5420-4. 
Fourie, M. M., Stein, D. J., Solms, M., Gobodo-Madikizela, P., \& Decety, J. (2019). Effects of early adversity and social discrimination on empathy for complex mental states: An fMRI investigation. Scientific Reports, 9(1), 12959. https://doi.org/10.1038/ s41598-019-49298-4

Gausel, N., \& Leach, C. W. (2011). Concern for self-image and social image in the management of moral failure: Rethinking shame. European Journal of Social Psychology, 41(4), 468-478. https:// doi.org/10.1002/ejsp.803

Govier, T., \& Verwoerd, W. J. (2011). Responsibility and responsiveness. Praxis, 13(20), 9-23.

Haffajee, F. (2020). The day the bottom fell out of South Africa - A triple pandemic has hit us. Daily Maverick. https://www.daily maverick.co.za/article/2020-07-15-the-day-the-bottom-fell-outof-south-africa-a-triple-pandemic-has-hit-us/.

Halabi, S., Dovidio, J. F., \& Nadler, A. (2008). When and how do high status group members offer help: Effects of social dominance orientation and status threat. Political Psychology, 29(6), 841-858. https://doi.org/10.1111/j.1467-9221.2008.00669.x

Hamann, R. (2020). Civil society groups that mobilised around COVID-19 face important choices. The Conversation. https:// theconversation.com/civil-society-groups-that-mobilised-aroundcovid-19-face-important-choices-140989.

Harth, N. S., Kessler, T., \& Leach, C. W. (2008). Advantaged group's emotional reactions to intergroup inequality: The dynamics of pride, guilt, and sympathy. Personality and Social Psychology Bulletin, 34(1), 115-129. https://doi.org/10.1177/0146167207 309193

Heywood, M. (2020). Scandal of the year: Covid-19 corruption. Daily Maverick. https://www.dailymaverick.co.za/article/2020-12-27scandal-of-the-year-covid-19-corruption/.

Hunt, J. S., Seifert, A. L., Armenta, B. E., \& Snowden, J. L. (2006). Stereotypes and prejudice as dynamic constructs: Reminders about the nature of intergroup bias from the Hurricane Katrina relief efforts. Analyses of Social Issues and Public Policy (ASAP), 6(1), 237-253. https://doi.org/10.1111/j.1530-2415.2006.00109.x

Imhoff, R., Bilewicz, M., \& Erb, H.-P. (2012). Collective regret versus collective guilt: Different emotional reactions to historical atrocities. European Journal of Social Psychology, 42(6), 729-742. https://doi.org/10.1002/ejsp.1886

Iyer, A., \& Leach, C. W. (2008). Emotion in inter-group relations. European Review of Social Psychology, 19(1), 86-125. https:// doi.org/10.1080/10463280802079738

Iyer, A., Leach, C. W., \& Crosby, F. J. (2003). White guilt and racial compensation: The benefits and limits of self-focus. Personality and Social Psychology Bulletin, 29(1), 117-129. https://doi.org/ 10.1177/0146167202238377

Iyer, A., Leach, C. W., \& Pedersen, A. (2004). Racial wrongs and restitutions: The role of guilt and other group-based emotions. In B. Doosje \& N. R. Branscombe (Eds.), Collective guilt: International perspectives (pp. 262-283). Cambridge University Press.

Jackman, M. R. (1994). The Velvet Glove: Paternalism and conflict in gender, class and race relations. University of California Press.

Jones, J. (2004). The impairment of empathy in goodwill whites for African Americans. In G. Yancy (Ed.), What White looks like: African-American philosophers on the Whiteness question. Routledge.

Krondorfer, B. (2015). Unsettling empathy: Intercultural dialogue in the aftermath of historical and cultural trauma. In P. GobodoMadikizela (Ed.), Breaking cycles of repetition: A global dialogue on historical trauma and memory (pp. 90-112). Opladen: Budrich.

Leach, C., Snider, N., \& Iyer, A. (2002). "Poisoning the consciences of the fortunate": The experience of relative advantage and support for social equality. In I. Walker \& H. J. Smith (Eds.), Relative deprivation: Specification, development, and integration (pp. 136-163). Cambridge University Press.

Leach, C. W., Iyer, A., \& Pedersen, A. (2006). Anger and guilt about ingroup advantage explain the willingness for political action. Personality and Social Psychology Bulletin, 32(9), 1232-1245. https://doi.org/10.1177/0146167206289729

Leach, C. W., Zeineddine, F. B., \& Čehajić-Clancy, S. (2013). Moral immemorial: The rarity of self-criticism for previous generations' genocide or mass violence. Journal of Social Issues, 69(1), 34-53. https://doi.org/10.1111/josi.12002

Lefko-Everett, K., Govender, R., \& Foster, D. (Eds.). (2017). Rethinking reconciliation. Evidence from South Africa. HSRC Press.

Meerholz, E. W., Spears, R., \& Epstude, K. (2019). Having pity on our victims to save ourselves: Compassion reduces self-critical emotions and self-blame about past harmful behavior among those who highly identify with their past self. PLOS ONE, 14(12), e0223945. https://doi.org/10.1371/journal.pone.0223945

Milazzo, M. (2016). On white ignorance, white shame, and other pitfalls in critical philosophy of race. Journal of Applied Philosophy, 34, 1-16. https://doi.org/10.1111/japp.12230

Moore, R. (2019). Resolving the tensions between white people's active investment in racial inequality and white ignorance: A response to Marzia Milazzo. Journal of Applied Philosophy, 36(2), 257267. https://doi.org/10.1111/japp.12306

Phyfer, J., Durrheim, K., \& Murray, A. J. (2020). Buttressing whiteness by confessing guilt and rejecting racism: A study of white-talk about paid domestic labour. South African Review of Sociology, 51(1), 3-16. https://doi.org/10.1080/21528586.2020.1741442

Powell, A. A., Branscombe, N. R., \& Schmitt, M. T. (2005). Inequality as ingroup privilege or outgroup disadvantage: The impact of group focus on collective guilt and interracial attitudes. Personality and Social Psychology Bulletin, 31(4), 508-521. https://doi. org/10.1177/0146167204271713

Prade-Weiss, J. (2020). Guilt-tripping the 'implicated subject': Widening Rothberg's concept of implication in reading Müller's The Hunger Angel. Journal of Perpetrator Research, 3, 42. https://doi. org/10.21039/jpr.3.1.64

Rad, M. S., Martingano, A. J., \& Ginges, J. (2018). Toward a psychology of Homo sapiens: Making psychological science more representative of the human population. Proceedings of the National Academy of Sciences, 115(45), 11401-11405. https://doi.org/10. 1073/pnas. 1721165115

Ratele, K., \& Laubscher, L. (2010). Making white lives: Neglected meanings of whiteness from apartheid South Africa. Psychology in Society, 83-99.

Roberts, S. O., Bareket-Shavit, C., Dollins, F. A., Goldie, P. D., \& Mortenson, E. (2020). Racial inequality in psychological research: Trends of the past and recommendations for the future. Perspectives on Psychological Science, 15(6), 1295-1309. https://doi.org/ $10.1177 / 1745691620927709$

Rothberg, M. (2019). The implicated subject: Beyond victims and perpetrators. Standford University Press.

Rucker, J., Duker, A., \& Richeson, J. (2019). Structurally unjust: How lay beliefs about racism relate to perceptions of and responses to racial inequality in criminal justice. Retrieved from http://psyar xiv.com/sjkeq.

Saguy, T., Chernyak-Hai, L., Andrighetto, L., \& Bryson, J. (2013). When the powerful feels wronged: The legitimization effects of advantaged group members' sense of being accused for harboring racial or ethnic biases. European Journal of Social Psychology, 43(4), 292-298. https://doi.org/10.1002/ejsp.1948

Saguy, T., \& Kteily, N. (2014). Power, negotiations, and the anticipation of intergroup encounters. European Review of Social Psychology, 251, 107-141957579. https://doi.org/10.1080/10463283. 2014.957579 
Salice, A., \& Montes Sánchez, A. (2016). Pride, shame, and group identification. Frontiers in Psychology, 7, 557. https://doi.org/10. 3389/fpsyg.2016.00557

Salter, P. S., Adams, G., \& Perez, M. J. (2017). Racism in the structure of everyday worlds: A cultural-psychological perspective. Current Directions in Psychological Science, 27(3), 150-155. https://doi. org/10.1177/0963721417724239

Sullivan, S. (2014). Good White people: The problem with middle-class White anti-racism. SUNY Press.

Swart, M. (2017). The moral imperative of the TRC and the question of collective guilt. In M. Swart \& K. V. Marle (Eds.), The limits of transition: The South African Truth and Reconciliation Commission 20 years on (pp. 147-168). Leiden: Brill Nijhoff.

Swartz, S. (2016). Another country: Everyday social restitution. BestRed, HSRC Press.

Swim, J. K., \& Miller, D. L. (1999). White guilt: Its antecedents and consequences for attitudes toward affirmative action. Personality and Social Psychology Bulletin, 25(4), 500-514. https://doi.org/ 10.1177/0146167299025004008

Turok, I., \& Visagie, J. (2021). COVID-19 amplifies urban inequalities. South African Journal of Science, 117(3/4). https://doi.org/ 10.17159/sajs.2021/8939

Unzueta, M. M., \& Lowery, B. S. (2008). Defining racism safely: The role of self-image maintenance on white Americans' conceptions of racism. Journal of Experimental Social Psychology, 44(6), 1491-1497. https://doi.org/10.1016/j.jesp.2008.07.011

Van Zyl-Hermann, D. (2018). Make Afrikaners great again! National populism, democracy and the new white minority politics in post-apartheid South Africa. Ethnic and Racial Studies, 41(15), 2673-2692. https://doi.org/10.1080/01419870.2017.1413202

Västfäll, D., Slovic, P., Mayorga, M., \& Peters, E. (2014). Compassion fade: Affect and charity are greatest for a single child in need. PLOS ONE, 9(6), e100115. https://doi.org/10.1371/journal.pone. 0100115

Verwoerd, W. J. (1999). Individual and/or social justice after Apartheid? The South African truth and reconciliation commission.
The European Journal of Development Research, 11(2), 115-140. https://doi.org/10.1080/09578819908426741

Verwoerd, W. J., \& Edlmann, T. (2021). 'Why did I die?' South African defence force conscripts pre- and post-1994. In J. D. Brewer \& A. Wahidin (Eds.), Ex-combatants' voices: Transitioning from war to peace in Northern Ireland, South Africa and Sri Lanka (pp. 207-236). Palgrave Macmillan.

Vice, S. (2010). How do I live in this strange place? Journal of Social Philosophy, 41(3), 323-342. https://doi.org/10.1111/j.1467-9833. 2010.01496.x

Vollhardt, J. R., \& Sinayobye Twali, M. (2016). Emotion-based reconciliation requires attention to power differences, critical consciousness, and structural change. Psychological Inquiry, 27(2), 136-143. https://doi.org/10.1080/1047840X.2016.1160762

Xu, H., Bègue, L., \& Shankland, R. (2011). Guilt and guiltlessness: An integrative review. Social and Personality Psychology Compass, 5(7), 440-457. https://doi.org/10.1111/j.1751-9004.2011.00364.x

Zaki, J. (2014). Empathy: A motivated account. Psychological Bulletin, 140(6), 1608-1647. https://doi.org/10.1037/a0037679

Zaki, J., \& Cikara, M. (2015). Addressing empathic failures. Current Directions in Psychological Science, 24(6), 471-476. https://doi. org/10.1177/0963721415599978

Positionality Statement Mindful that our identities can influence our research (Roberts et al., 2020), the authors wish to provide the reader with potentially relevant information about our backgrounds with respect to race and nationality: MMF and WJV both identify as White and South African. While conscious of the intersectional complexity within the White South African identity (with regard to, e.g., generational background, gender, religion, and language), we believe referring to White South Africans is warranted, without intending to oversimplify, given the legacies of systematic racial discrimination under colonialism and apartheid in South Africa. 